\title{
RECENT OBSERVATIONS OF WOOD DUCKS IN EAST-CENTRAL SASKATCHEWAN
}

P. M. BROWNE and D. A. DUFFUS, Ducks Unlimited (Canada), P.O. Box 4465, 1606 - 4th Avenue, Regina, Saskatchewan. S4P 3W7.

The Wood Duck has been recorded in small numbers throughout eastern Saskatchewan. The first documented observations were made in the late 19th century, with breeding records from Indian Head in 1888 and Cumberland House in $1890 .^{21356}$ Since that time, Wood Ducks have been recorded with young on the Qu'Appelle River, east of Craven. ${ }^{4}$ A number of other breeding records have been submitted, notably from southeastern Saskatchewan, around Estevan (D. A. Duffus and R. J. Santo, pers. comm.). This note describes recent observations of Wood Ducks in east-central Saskatchewan.

\section{CUMBERLAND HOUSE}

Staff of Ducks Unlimited (Canada) made several observations of this species in the Cumberland Marshes complex during 1980. (Table 1 and Figure $1 \mathrm{~A})$. In 1979, banders from the United States Fish and Wildife Service USFWS) banded a lone drake on Waterhen Lake, Cumberland. All of the Wood Ducks observed in the area were dentified as males.

\section{DVERFLOWING RIVER and LEAF AKE}

The Overflowing River is a deep, harrow, meandering channel that drains nto the southwest corner of Leaf Lake rom the Pasquia Hills (Figure 1B). Its panks are densely vegetated by willow Salix spp.). The uplands adjacent to the fiver are primarily willow/sedge neadows (Carex spp.) and, as elevation ncreases, mature hardwood stands
(Populus spp.; UImus spp.; Fraxinus spp.; Acer spp.) occur, often adjacent to the river itself.

On 18-19 September 1980 we observed between 25 and 30 Wood Ducks using the overhanging willows along the river as loafing areas. The birds were observed as individuals and in small groups, flying out from the willows at distances ranging from $10 \mathrm{~m}$ to $75 \mathrm{~m}$ ahead of us. During the first surveys, the distance at which a bird or flock flushed seemed to be primarily a function of how clearly it could see us. Larger groups would flush in one's and two's rather than as a group. Once in the air, the birds generally gained altitude rapidly and circled around behind us, landing downstream, permitting an accurate estimate of numbers. We repeated this exercise three times over a period of two days, each time arriving at a similar number. The birds became more nervous with each "survey" and flushed farther from the boat each time.

We managed to identify three adult males and six adult females. The remainder of the birds observed were indistinctly marked, and superficially resembled adult females, although their plumage was duller and the eye-rings were absent, features characteristic of immature birds. ${ }^{1}$

There have been no breeding records reported for the Wood Duck along the Overflowing River.

Earlier this century, the Wood Duck 


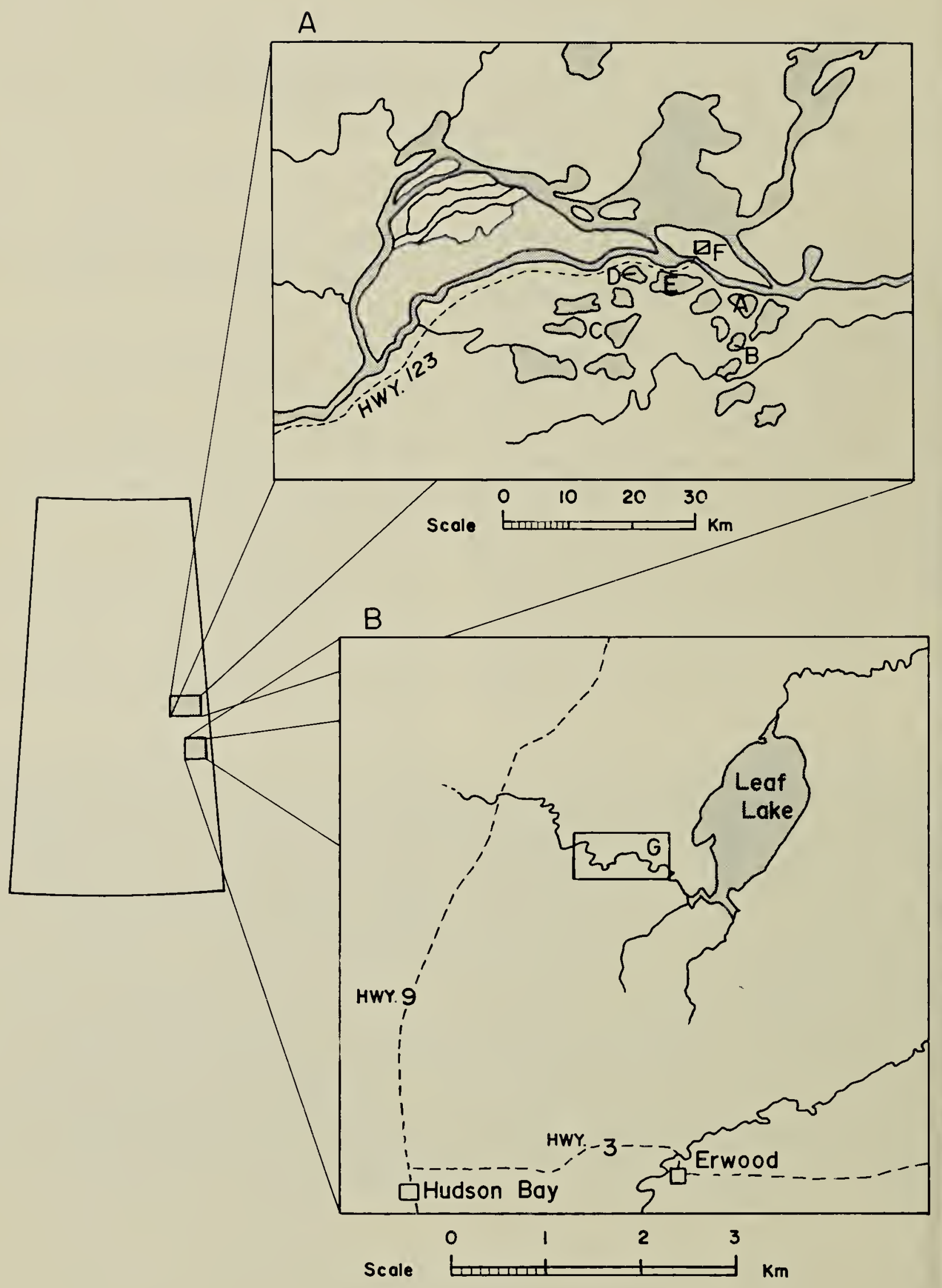

Figure 1. A - N. McGregor Lake, B - Beaton Lake, C - West Channel, D - Waterh Lake, E - Egg Lake, F-Cumberland House, G - Section of Overflowing Riv where observations were made. 
Table 1. WOOD DUCK OBSERVATIONS - CUMBERLAND MARSHES, 1979 AND 1980.

$\begin{array}{llcl}\text { Date } & \text { Location } & \begin{array}{c}\text { No. of Birds } \\ \text { (all males) }\end{array} & \begin{array}{l}\text { Authority } \\ 1979\end{array} \\ \text { 31 May } 1980 & \text { Waterhen Lake } & 1 & \text { Banded by USFWS } \\ \text { 28 July } 1980 & \text { North McGregor Lake } & 1 & \text { D. Phillips } \\ \text { 19 Sept. } 1980 & \text { Beaton Lake } & 1 & \text { D. Phillips } \\ \text { 22 Sept. } 1980 & \text { Beaton Lake } & 3 & \text { D. Phillips } \\ \text { 26 Sept. } 1980 & \text { Beaton Lake } & 22 & \text { D. Phillips } \\ \text { 6 Oct. } 1980 & \text { West Channel } & 1 & \text { D. Phillips } \\ \end{array}$

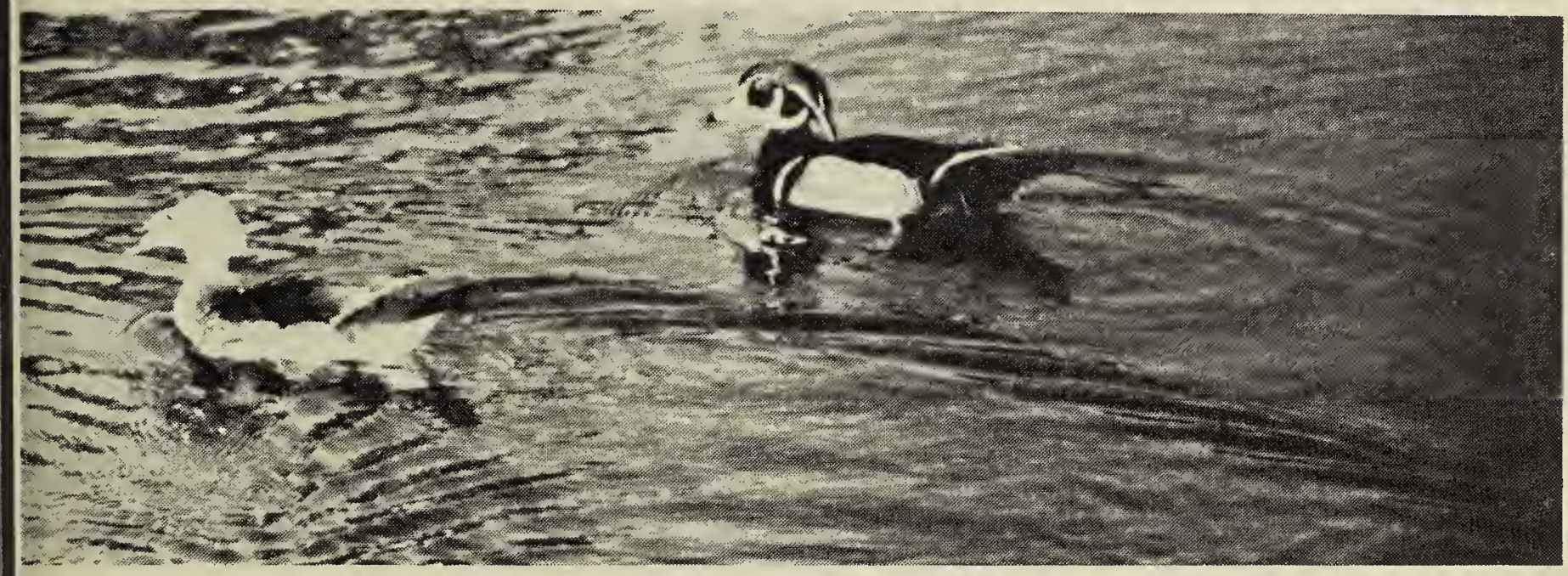

Wood Ducks.

Fred W. Lahrman

seemed to be on the brink of extinction throughout many parts of its range in North America. ${ }^{5}$ An expansion in its range seems to be the present trend. ${ }^{5}$ Attempts to encourage this trend are underway throughout the western provinces, primarily in British Columbia and Manitoba. In Saskatchewan, efforts have been undertaken by local wildlife federation branches to provide suitable nesting sites by erecting nest boxes in areas where birds have been sighted. Further investigation may reveal, however, that there is already a viable, but previously underestimated. breeding population in east-central Saskatchewan.

We wish to thank the following people for their support: D. A. Phillips, D. F. Hooey, R.W. Boychuk and D.J. Munro. Appreciation is shown also to J. B. Gollop for critical review of the manuscript.
'BELLROSE, F. C. 1976. Ducks, geese and swans of North America. Stackpole? Books, Harrisburg, Pennsylvania.

${ }^{2}$ CALLIN, E. M. 1980. Birds of the Qu'Appelle, 1857-1979. Sask. Nat. Hist. Soc. Spec. Publ. 13, Regina, Saskatchewan.

${ }^{3}$ GODFREY, E. W. 1966. Birds of Canada. Nat. Mus. Canada Bull. 203, Ottawa.

${ }^{4}$ LIEFFERS, V. and D. HATCH. 1977. Qu'Appelle waterfowl resource inventory. Wildl. Technical Report 77-20. Qu'Appelle Implementation/Saskatchewan Tourism and Renewable Resources, Regina.

${ }^{5}$ PALMER, RALPH S. (Ed). Handbook of North American birds. Volume 3 Waterfowl (concluded), Yale Univ. Press.

${ }^{6}$ SALT, W. R. and J. R. SALT. The birds of Alberta with their ranges in Saskatchewan and Manitoba. Hurtig Publishers, Edmonton, Alberta. 